\title{
Ascending Limb of Henle's Loop
}

National Cancer Institute

\section{Source}

National Cancer Institute. Ascending Limb of Henle's Loop. NCI Thesaurus. Code C32154.

The ascending limb of the U-shaped portion of the renal tubule. 